\title{
Anxiety, attitude and information use behaviour of school teachers in central schools
}

\author{
Suresh Jange \\ Head \& Assistant Librarian, \\ Virtual Learning Resource Centre, \\ Gulbarga University, Gulbarga, \\ Karnataka, India, \\ e-mail: suresh jange@rediffmail.com
}

And

Suresh Surpur

Librarian,

Aditya Birla Public School.

Adityanagar, Malkhed, Gulbarga,

Karnataka,

India,

\section{Abstract}

The research paper presents the findings of a study that explores the use of school libraries and attitude, anxiety and level of satisfaction of teachers towards using information sources and services, level of collaboration between librarians / library staff and teaching activities, searching methods, difficulties faced and level of association between personal characteristics and use of library resources.

A questionnaire survey was conducted by distributing 195 questionnaires to the teachers of Central Board of Secondary Education (CBSE) schools in Hyderabad Karnataka, India covering about 12 CBSE schools of the region, obtaining 175 questionnaires (89.74\%).

The results showed that about less than half of the teachers generally did use their school libraries daily mainly to refer books, which indicates that more than half of the teachers do not use much of their information resources effectively, mainly due to the inadequacy of their school libraries in terms of educational materials. In addition, teachers typically did not collaborate with their school librarian in planning their lessons or other academic activities, although $61.2 \%$ agree that they collaborate with each other.

The teachers of school libraries responded were above 40 years of age accounts to $36.6 \%$ and $52 \%$ of the school teachers possess Post graduation and their experience would serve school libraries, strength in building model library. The study provided an insight into the situation of school library use by teachers in Karnataka, India and their related factors. This insight could in turn yield initiatives on various aspects of school library research, such as the role of the school library in the school curriculum, and how school library usage can be improved by teachers and school librarian through better collaboration.

The study proposes that teachers are the first to get themselves more familiarized in utilizing and understanding the role of school libraries in inculcating and motivating students to develop information culture and the role of librarian in developing innovative services through school library outreach programmes. 
The paper notifies the significance of the school library especially in the Indian context in the school curriculum, presents the elements that can contribute to or work against the use of the school library by teachers, and most importantly, the results of the demands the ways and means to improve the situation for better utilization of information resources by the library to support curriculum and develop sense of collaboration among school library.

Keywords: School Libraries, Teachers, India, Hyderabad Karnataka, Central Schools, CBSE Schools, Information Use Behaviour

\title{
INTRODUCTION
}

\author{
'The School Library is the soul, the core and the pivot around which academic \\ life in the school revolves'
}

Schools have the continuous task of educating the nation for the future has to keep up with both the immediate and impending changes that permeate society. Education has now shifted from being teacher-centric to student-centric - in other words from directed instruction to active learning and knowledge discovery and construction. Thus, due to the new demands that the current information age places on individuals, schools no longer have the prime objective of helping students to read. Instead, they are expected to inculcate skills that go beyond that basic ability to read. Students now need to be trained and groomed on how to think and think creatively and critically. Teachers need to use a variety of information sources in their lessons so as to keep their students interested and their lessons current and informative. Foo (1999) stated that the school library plays a critical and crucial role in "supporting the new age education", and that this is even more so in the new millennium when the nation propels itself towards a "truly information society". He also recommended that adequate emphasis and attention should be placed on school libraries so as to ensure that they have sufficient staff, resources and opportunities for development, growth and expansion.

With the changing concept in a new era of education after independence of the country in 1947, the school library as a repository of all kinds of learning materials that includes both print and electronic resources. The need of the hour is therefore, the important part of school libraries have to play a significant role in national service and recognition of joint efforts of teachers and librarians to make the school as a model library and future of the society. In the present democratic set-up of India there is now a change in the educational philosophy and consequently in the methods of teaching. The role of education today is to promote intellectual and emotional development of the child through an effective and progressive system of primary and secondary education. Ranganathan (1962) puts it, "the result of modern re-thinking on education is to make the library the heart of the school, from which every activity in the school radiates and by which it all gets irradiated.

In this context, it has been found necessary to study the role of library in catering to the academic needs of teachers and their use pattern, collaboration with librarian, level of satisfaction towards library resources, services and facilities and anxiety towards using information resources. The findings are intended to help identify factors that hinder teachers from using their school libraries and library resources effectively, and from actively collaborating with school librarians. Consequently, corrective necessary measures should emerge, capable of improving the overall educational environment in the central schools of India. Hence the study is undertaken to study the library use patterns of school teachers in CBSE Schools of India especially Hyderabad Karnataka Region. 


\section{OBJECTIVES OF THE STUDY}

The objective of the study is to determine the use of School libraries by Teachers in Central Board of Secondary Education (CBSE) schools of Hyderabad Karnataka region in India to understand the frequency and purpose of visiting to the school library, explore the Information sources and services used by the teachers for their academic and teaching pursuit, attitude and level of satisfaction of teachers towards using information sources and services, level of collaboration between librarians / library staff and teaching activities, methods adopted for searching information in libraries, difficulties faced and level of association between personal characteristics and use of library resources.

\section{METHODOLOGY}

Research data collected using a questionnaire that had been pre-tested with teachers from both preparatory and secondary levels and incorporated accordingly. The first part of the questionnaire dealt with the general profile of the respondents and collected information about their gender, teaching experience, and academic and professional qualifications. The second part of the questionnaire investigated various aspects of the use of school libraries by teachers, such as the frequency of use of the school library, the type of library resources used and for what purposes, and the perception of teachers of the usefulness and adequacy of their school library resources and about the collaborative relationship between teachers and their school librarian, and the problems faced in their collaboration efforts. A total of 195 questionnaires were distributed to the teachers of CBSE schools in Hyderabad Karnataka covering about 12 CBSE schools of the region. Out of which, 175 questionnaires were duly received from teachers $(89.74 \%)$.

The statistical tests mainly Chi-Square Test has been applied to test the hypothesis of the study at 0.05 level of significance.

\section{HYPOTHESES}

- There is an association between Sex and qualification of the respondents and use of information sources

- There is an association between Sex and qualification of the respondents and satisfaction towards information sources and services

- There is no association between Sex and qualification of the respondents and anxiety level of teachers to use information resources.

\section{LITERATURE REVIEW}

An examination of the literature, only a few studies of school libraries have been reported in India, which reveals that the school libraries have not received much attention. Similar studies conducted to investigate the nature and extent of use of school libraries by teachers in preparatory and secondary schools in Oman (Bouazza and Al-Mufaraji, 2005). Majid and Mokhtar (2005) to explored the use of school libraries and their resources by teachers, their level of collaboration with their school librarian, and the problems faced by them in using these libraries through questionnaire survey of 76 teachers from seven schools in Singapore. The results showed that teachers generally did not use their school libraries and 
various information resources effectively, mainly due to the inadequacy of their school libraries in terms of educational materials. A study was conducted to connect every school in the UK to the Internet by 2002 raises many questions and the impact of the Internet in schools is studied from the perspective of teachers, responsible for equipping children with Internet skills (Irvine and Williams, 2002). While Wishart (2000) studied eight UK secondary schools concerning their use of multimedia encyclopedias on CD-ROM. Similar studies emphasizing the role of school libraries and its usage were reported by Matsudo (2000), Cron and Einsatz (1998), Burks (1996), Deusen, (1996), Olen, (1995) and Zaman (1994).

In India, Prasad (2004) attempted to make a realistic study of the existing conditions of school libraries in rural Karnataka State, India w.r.t physiographic conditions, infrastructural, educational, communication and mass communication facilities, socioeconomic conditions of the population, and access to resources including libraries, computers and the Internet etc., have been collected and analyzed. It was found that the schools in villages do not enjoy the advantage of having good libraries, computers or other ICT facilities. While Kumar (1997) draws the attention of present state of government aided schools libraries in Delhi, India, including: lack of additional library staff; acquisitions; lack of space and furniture; library grants; loss and damage of books; lack of channels for promotion; lack of guidelines regarding duties; and stock verification.

\section{RESULTS AND DISCUSSION}

An attempt has been made to analyze and interpret the data collected from respondents of the study and determine the use of school libraries by teachers in the Hyderabad Karnataka Region.

Table 1: Sex of the Respondents

\begin{tabular}{|c|l|c|c|}
\hline \multicolumn{2}{|c|}{ Sex } & Frequency & Percent \\
\hline \multirow{4}{*}{ Valid } & Male & 89 & 50.9 \\
\cline { 2 - 4 } & Female & 86 & 49.1 \\
\cline { 2 - 4 } & Total & 175 & 100.0 \\
\hline
\end{tabular}

It is found from the table that, the percentage of male and female teachers covered in the study is more or less of same proportion, i.e. male teachers $(50.9 \%)$ and female teachers $(49.1 \%)$.

Table 2: Age Wise Distribution of the Respondents

\begin{tabular}{|l|l|c|c|}
\hline \multicolumn{2}{|c|}{ Age of the Respondents } & Frequency & Percent \\
\hline \multirow{5}{*}{ Valid } & Less than 25 years & 7 & 4.0 \\
\cline { 2 - 4 } & $26-30$ Years & 30 & 17.1 \\
\cline { 2 - 4 } & $31-35$ Years & 32 & 18.3 \\
\cline { 2 - 4 } & $36-40$ Years & 42 & 24.0 \\
\cline { 2 - 4 } & 40 and above & 64 & 36.6 \\
\cline { 2 - 4 } & Total & 175 & 100.0 \\
\hline
\end{tabular}


From the above table, it is observed that, respondents above 40 years of age accounts to $36.6 \%$ and they are followed by respondents in the age group of $36-40$ years (24\%), 31-35 years $(18.3 \%), 26-30$ years $(17.1 \%)$ and Less than 25 years $(4 \%)$. Thus, the major proportion of respondents belongs to age group between 40 and above years.

Table 3: Qualification of the Respondents

\begin{tabular}{|c|l|c|c|}
\hline \multicolumn{2}{|c|}{ Qualification } & Frequency & Percent \\
\hline \multirow{4}{*}{ Valid } & Degree & 84 & 48.0 \\
\cline { 2 - 4 } & $\begin{array}{l}\text { Post } \\
\text { Graduation }\end{array}$ & 91 & 52.0 \\
\cline { 2 - 4 } & Total & 175 & 100.0 \\
\hline
\end{tabular}

Table shows that $52 \%$ of the school teachers possess Post graduation while $48 \%$ possess degree only. Thus, there is a little variation between teachers having degree and Post graduation qualification.

Table 4: Frequency of Visit to the Library

\begin{tabular}{|c|l|c|c|c|}
\hline \multicolumn{2}{|l|}{ Frequency Of Visit } & Frequency & Percent & $\begin{array}{c}\text { Cumulative } \\
\text { Percent }\end{array}$ \\
\hline \multirow{4}{*}{ Valid } & Almost daily & 82 & 46.9 & 46.9 \\
\cline { 2 - 5 } & Once week & 70 & 40.0 & 86.9 \\
\cline { 2 - 5 } & once month & 11 & 6.3 & 93.1 \\
\cline { 2 - 5 } & Several times & 11 & 6.3 & 99.4 \\
\cline { 2 - 5 } & Never & 1 & 0.6 & 100.0 \\
\cline { 2 - 5 } & Total & 175 & 100.0 & \\
\hline
\end{tabular}

From the table it is noted that nearly half of the respondents visit to the library every day $(46.9 \%)$ and $40 \%$ of them visit once a week. However very few teachers visit once a month or so $(6.3 \%)$. Thus, almost all the respondent's visit the library for their school related activities.

Table 5: Purpose of Visiting to the Library

\begin{tabular}{|l|c|c|}
\hline Purpose & Frequency & Percentage \\
\hline To take the students to Library & 22 & $12.6 \%$ \\
\hline To Refer books & 161 & $92 \%$ \\
\hline To prepare for class notes & 46 & $26.3 \%$ \\
\hline $\begin{array}{l}\text { To refer AV / Video / CD } \\
\text { Materials }\end{array}$ & 31 & $17.7 \%$ \\
\hline
\end{tabular}


It is observed from the study that majority of the respondents visit library to refer books (92\%), followed with a purpose to prepare for class notes (26.3\%), refer AV / Video / CD Materials $(17.7 \%)$ and to take the students to Library (12.6\%).

Table 6 shows that, among the various information sources used by the respondents, Books (76.6\% and $16 \%$ ) followed by Newspapers (44.6\% and $30.9 \%$ ), Dictionaries $(41.7 \%$ and $28 \%$ ) and Journals (25.7\% and $46.3 \%$ ) are very frequently and moderately used information resources. On the contrary, Encyclopedias, Internet and AV / Video / CD ROMs are less used information sources compared to other sources. Thus, Books and Newspapers are the popular sources used by teachers.

Table 6: Information Sources Used For Academic/ Teaching Purpose

\begin{tabular}{|l|c|c|c|c|}
\hline Information Sources & Not used & Rarely used & $\begin{array}{c}\text { Moderately } \\
\text { used }\end{array}$ & $\begin{array}{c}\text { Very } \\
\text { frequently } \\
\text { used }\end{array}$ \\
\hline Books / Text books & $2(1.1)$ & $11(6.3)$ & $28(16.0)$ & $134(76.6)$ \\
\hline News paper & $4(2.3)$ & $39(22.3)$ & $54(30.9)$ & $78(44.6)$ \\
\hline Journals / Magazines & $8(4.6)$ & $41(23.4)$ & $81(46.3)$ & $45(25.7)$ \\
\hline Dictionaries & $10(5.7)$ & $43(24.6)$ & $49(28.0)$ & $73(41.7)$ \\
\hline Encyclopedia's & $19(10.9)$ & $82(46.8)$ & $53(30.2)$ & $21(12.0)$ \\
\hline Internet & $28(16.0)$ & $67(38.2)$ & $56(32)$ & $24(13.7)$ \\
\hline AV / Video / CD ROMs & $10(5.7)$ & $67(38.2)$ & $58(33.1)$ & $40(22.8)$ \\
\hline
\end{tabular}

Table 7: Level of Collaboration with the Librarian in Planning Class Lesson

\begin{tabular}{|c|l|c|c|}
\hline \multicolumn{2}{|c|}{ Collaboration } & Frequency & Percent \\
\hline \multirow{3}{*}{ Valid } & Yes & 104 & 59.4 \\
\cline { 2 - 4 } & No & 71 & 40.5 \\
\cline { 2 - 4 } & Total & 170 & 97.1 \\
\hline
\end{tabular}

It is observed that, the respondents believe they have collaboration with the librarian or library staff in planning their class lessons, School projects and other activities (59.4\%), while the rest do not indicate such collaboration with the librarian. 
Table 8: Collaborative Activities with the Librarian

\begin{tabular}{|l|c|c|c|}
\hline Collaboration Activities & Most of time & occasionally & Never \\
\hline $\begin{array}{l}\text { Plan lessons, School projects \& } \\
\text { other activities }\end{array}$ & $50(28.6)$ & $55(31.4)$ & $4(2.3)$ \\
\hline $\begin{array}{l}\text { Identify useful resources for } \\
\text { lessons }\end{array}$ & $45(25.7)$ & $60(34.3)$ & $2(1.1)$ \\
\hline $\begin{array}{l}\text { Discuss \& decide on library } \\
\text { purchases }\end{array}$ & $21(12.0)$ & $73(41.7)$ & $9(5.1)$ \\
\hline
\end{tabular}

As librarian deals with universe of knowledge, involvement of librarian expertise in planning class room is essential and as such opinion was sought from respondents of the study. $28.64 \%$ of the teachers indicated that, they collaborate with librarian in Planning lessons, School projects and other activities and is followed in identifying useful resources for lessons $(25.7 \%)$ and just $12 \%$ regarding purchases. Thus, the level of involvement of librarian in schools related to school academic activities is less.

Table 9: Satisfaction with Information Sources and Services

\begin{tabular}{|l|c|c|c|c|}
\hline \multicolumn{1}{|c|}{$\begin{array}{c}\text { Information source and } \\
\text { services }\end{array}$} & Very good & Good & Poor & Not at all \\
\hline Books & $121(69.1)$ & $53(30.2)$ & $1(0.6)$ & - \\
\hline Journals / Magazines & $77(44)$ & $95(54.2)$ & $2(1.1)$ & $1(0.6)$ \\
\hline News papers & $92(52.5)$ & $80(44)$ & $2(1.1)$ & $1(0.6)$ \\
\hline AV / Video materials & $49(28.0)$ & $83(47.4)$ & $20(11.4)$ & $6(3.4)$ \\
\hline Internet services & $39(22.3)$ & $67(38.3)$ & $26(14.9)$ & $16(9.1)$ \\
\hline Borrowing facility & $53(30.3)$ & $61(34.9)$ & $15(8.6)$ & $13(7.4)$ \\
\hline Attending your Information queries & $32(18.3)$ & $89(50.9)$ & $12(6.9)$ & $5(2.9)$ \\
\hline
\end{tabular}

It is found that, majority of the respondents are satisfied with the availability of books $(69.1 \%$ $\& 30.2 \%)$ for their reference in the library indicating very good and good respectively. This is followed by Newspapers (52.5\% \& 44\%), Journals / Magazines (44\% \& 54.2\%), AV / Video materials $(28 \%$ \& $47.4 \%)$, Internet services $(22.3 \%$ \& $38.3 \%)$, Borrowing facility $(30.3 \%$ \& $34.9 \%)$ and attending information queries (18.3\% \& 50.9\%) indicating very good and good respectively.

Table 10: Level of Anxiety towards Using Information Sources in Library

\begin{tabular}{|l|l|c|c|c|}
\hline \multicolumn{2}{|c|}{ Anxiety in using Library } & Frequency & Percent & $\begin{array}{c}\text { Cumulative } \\
\text { Percent }\end{array}$ \\
\hline \multirow{4}{*}{ Valid } & Not at all & 7 & 4.0 & 4.3 \\
\cline { 2 - 5 } & To little extent & 6 & 3.4 & 8.0 \\
\cline { 2 - 5 } & To some extent & 52 & 29.7 & 40.1 \\
\cline { 2 - 5 } & To full extent & 87 & 49.7 & 87.7 \\
\cline { 2 - 5 } & To Greater extent & 23 & 13.1 & 100.0 \\
\cline { 2 - 5 } & Total & 162 & 92.6 & \\
\hline
\end{tabular}

It is very much clear from the table that majority of the respondents are anxious to use information sources in library to a greater (13.1\%) and $49.7 \%$ to full extent. And 
$29.7 \%$ of respondent's level of anxiousness to visit and use the library to some extent is $29.7 \%$.

Table 11: Motivating Students to Visit the Library

\begin{tabular}{|c|l|c|c|c|}
\hline \multicolumn{2}{|c|}{ Motivating students } & Frequency & Percent & Cumulative Percent \\
\hline \multirow{4}{*}{ Valid } & Yes & 168 & 96 & 97.6 \\
\cline { 2 - 5 } & No & 7 & 4 & 100.0 \\
\cline { 2 - 5 } & Total & 166 & 94.9 & \\
& & & & \\
\hline
\end{tabular}

It is observed from the table that, majority of the school teachers (96\%) motivate their students to visit the library and inculcate reading habits and develop sense of information society for the future.

Table 12: Methods Used in Searching Information Sources in the Library

\begin{tabular}{|l|c|c|}
\hline Methods of Searching & Frequency & Percent \\
\hline Consult Catalogues & 46 & $26.3 \%$ \\
\hline Approach to Librarian & 142 & $81.1 \%$ \\
\hline Directly browse to shelves & 47 & $26.9 \%$ \\
\hline $\begin{array}{l}\text { Seek from } \\
\text { Colleagues }\end{array}$ & 28 & $16.0 \%$ \\
\hline Delegate work to students & 10 & $5.7 \%$ \\
\hline
\end{tabular}

It is clearly depicted from the table that, $81.1 \%$ of the respondents approach to the librarian for books or any other information resources than catalogue or any other mode of searching and thus librarian is direct approach point for searching information in the library. This is followed by directly browsing the Shelves (26.9\%), seeking help from colleagues (16\%) and very small percentage (5.7\%) delegate work to the students.

Table 13: Overall Effectiveness of School Library

\begin{tabular}{|l|l|c|c|c|}
\hline $\begin{array}{l}\text { Effectiveness of } \\
\text { school library }\end{array}$ & Frequency & Percent & Cumulative Percent \\
\hline \multirow{4}{*}{ Valid } & Very Effective & 72 & 41.1 & 41.3 \\
\cline { 2 - 5 } & Effective & 87 & 49.7 & 90.7 \\
\cline { 2 - 5 } & Somewhat & 13 & 7.4 & 98.3 \\
\cline { 2 - 5 } & Very Ineffective & 3 & 1.7 & 100.0 \\
\cline { 2 - 5 } & Total & 172 & 98.3 & \\
\hline
\end{tabular}

The Table shows that library is an indispensable instrument in School education and the school teachers indicated that the school Library is very effective (41.15) and effective $(49.7 \%)$. Thus, majority of the school teachers opined that school libraries in CBSE schools are quite effective in supporting information to the teachers. 
Table 14: Difficulties Faced in Using and Searching Information

\begin{tabular}{|l|c|c|}
\hline \multicolumn{1}{|c|}{ Difficulties } & Frequency & Percent \\
\hline Lack of Time & 118 & $67.4 \%$ \\
\hline Do not have better library resources & 16 & $9.1 \%$ \\
\hline $\begin{array}{l}\text { Difficult in locating / searching } \\
\text { information }\end{array}$ & 16 & $9.1 \%$ \\
\hline $\begin{array}{l}\text { Lack of training in using information } \\
\text { sources }\end{array}$ & 22 & $12.6 \%$ \\
\hline Library collections are disorganized & 4 & $2.3 \%$ \\
\hline No proper sitting arrangement in Library & 4 & $2.3 \%$ \\
\hline
\end{tabular}

Majority of the respondents $(67.4 \%)$ feel that they don't get sufficient time to use or search information in the library may be due to hectic classes and assignment and however the other problems are of very less significance.

Table 15: Sex and Qualification of Respondents vs. Use of Information Sources

\begin{tabular}{|l|c|c|c|c|}
\hline \multirow{2}{*}{$\begin{array}{l}\text { Information } \\
\text { Sources }\end{array}$} & \multicolumn{2}{|c|}{ Sex } & \multicolumn{2}{c|}{ Qualification } \\
\cline { 2 - 5 } & $\begin{array}{c}\text { Chi-Square } \\
\text { Value }\end{array}$ & Significance & $\begin{array}{c}\text { Chi-Square } \\
\text { Value }\end{array}$ & Significance \\
\hline Books / Text Books & 2.797 & 0.424 & 2.292 & 0.514 \\
\hline News paper & 4.873 & 0.181 & 3.906 & 0.272 \\
\hline $\begin{array}{l}\text { Journals / } \\
\text { Magazines }\end{array}$ & 8.583 & $0.035^{*}$ & 2.613 & 0.455 \\
\hline Dictionaries & 16.938 & $0.001^{*}$ & 1.715 & 0.634 \\
\hline Encyclopedias & 4.632 & 0.204 & 3.621 & 0.305 \\
\hline Internet & 0.274 & 0.965 & 4.925 & 0.177 \\
\hline AV/Video/CD ROMs & 3.331 & 0.343 & 6.042 & 0.110 \\
\hline
\end{tabular}

The results of Chi-square value indicate that, there is an association between Sex of the respondents and use of information sources i.e. Journals / Magazines and Dictionaries, Hence the null hypothesis is rejected, while the other variable does not show any association between each other and hence, null hypothesis is accepted.

Similarly, there is no association between qualification of the respondents and use of different information sources and hence the null hypothesis is accepted in totality. 
Table 16: Sex and Qualification of Respondents V/S Collaboration with Library Staff in Class Room

\begin{tabular}{|c|c|c|c|c|}
\hline \multirow{2}{*}{ Collaboration } & \multicolumn{2}{|c|}{ Sex } & \multicolumn{2}{c|}{ Qualification } \\
\cline { 2 - 5 } & $\begin{array}{c}\text { Chi-Square } \\
\text { Value }\end{array}$ & Significance & $\begin{array}{c}\text { Chi-Square } \\
\text { Value }\end{array}$ & Significance \\
\hline Yes & 11.702 & $.001^{*}$ & 4.547 & $0.033^{*}$ \\
\hline No & \multicolumn{2}{|c}{ * Results are significant } \\
\hline
\end{tabular}

As seen from the Chi-square value, there is an association between Sex and qualification of the respondents and level of collaboration with librarian. Thus, the null hypothesis is rejected showing relation to each other.

Table 17: Sex and Qualification of Respondents vs. Level of Satisfaction towards Information Sources and Services

\begin{tabular}{|l|c|c|c|c|}
\hline \multirow{2}{*}{$\begin{array}{l}\text { Information Sources \& } \\
\text { Services }\end{array}$} & \multicolumn{2}{|c|}{ Sex } & \multicolumn{2}{c|}{ Qualification } \\
\cline { 2 - 5 } & $\begin{array}{c}\text { Chi-Square } \\
\text { Value }\end{array}$ & Significance & $\begin{array}{c}\text { Chi-Square } \\
\text { Value }\end{array}$ & Significance \\
\hline Books & 2.684 & 0.261 & 5644 & .059 \\
\hline Journals / Magazines & 4.548 & 0.208 & 5.734 & 0.125 \\
\hline News papers & 1.442 & 0.696 & 2.147 & 0.542 \\
\hline AV / Video & 1.058 & 0.787 & 10.771 & $.013^{*}$ \\
\hline Internet Services & 2.285 & 0.515 & 6.411 & 0.093 \\
\hline Borrowing facility & 9.065 & $.028^{*}$ & 5.714 & 0.126 \\
\hline $\begin{array}{l}\text { Attending your } \\
\text { Information queries }\end{array}$ & 8.334 & $.040^{*}$ & 5.635 & 0.131 \\
\hline
\end{tabular}

${ }^{*}$ Results are significant

There is an association between Sex of the respondents and satisfaction towards information sources and services i.e. borrowing facility and attending information queries and hence the null hypothesis is rejected, while the other variable does not show any association between each other and hence, null hypothesis is accepted. Similarly, There is an association between qualification of the respondents and satisfaction towards information sources and services mainly newspaper and the rest does not show any association between them. Hence, the null hypothesis is accepted.

Table 18: Sex and Qualification of Respondents vs. Level of Anxiety towards Information Sources

\begin{tabular}{|c|c|c|c|c|}
\hline \multirow[b]{2}{*}{ Level of anxiety } & \multicolumn{2}{|c|}{ Sex } & \multicolumn{2}{|c|}{ Qualification } \\
\hline & $\begin{array}{c}\text { Chi-Square } \\
\text { Value }\end{array}$ & Significance & $\begin{array}{c}\text { Chi-Square } \\
\text { Value }\end{array}$ & Significance \\
\hline Not at all & \multirow{5}{*}{4.968} & \multirow{5}{*}{$0.291^{* *}$} & \multirow{5}{*}{5.153} & \multirow{5}{*}{$0.272^{\star \star}$} \\
\hline To Little extent & & & & \\
\hline To Some extent & & & & \\
\hline To Full extent & & & & \\
\hline To greater extent & & & & \\
\hline
\end{tabular}

The results of Chi-square value indicate that, there is no association between Sex and qualification of the respondents and anxiety level of teachers to use information resources. Hence the null hypothesis is accepted. 


\section{CONCLUSION}

Although the teacher respondents of the study are positively noted that Library is very essential for school forming integral part of school system and rated their library use skills as very good (40\%), but less than half of them visit to the library every day (46.9\%). Besides, one third of the teachers indicated that, they collaborate with librarian in Planning lessons, School projects and other activities. The findings are of course encouraging in the context of central CBSE school environment, but still there is a need to strengthen the school libraries and efforts be made by librarian to educate and train in using optimum resources of the library and the role of librarian in school academic and lesson plan activities cannot be ignored and need for adequacy of information resources both print and e-resources.

\section{REFERENCES}

Bouazza, Abdelmajid and Al-Mufaraji, Moosa N (2005). Use of school libraries by teachers: the case of Oman. Libri, 55 (2-3), 240-247.

Burks, F (1996). Student use of school library media centers in selected high schools in Greater Dallas Fort Worth, Texas. School Library Media Quarterly, 24(3), 143-9.

Cron, K (1998). EDV-Einsatz in Schulbibliotheken. EDP use in school libraries. Schulbibliothek Aktuell, (4), 391-4.

Deusen, J. D. V (1996). An analysis of the time use of elementary school library media specialists and factors that influence it. School Library Media Quarterly, 24(2), 85-92.

Foo, S (1999). Media resource libraries in Singapore schools: challenges and opportunities, Singapore Journal of Library and Information Management, 28, 73-85.

Irvine, $\mathrm{H}$ and Williams, $\mathrm{P}$ (2002). Internet use in schools: an investigation into the experiences, abilities and attitudes of teachers and pupils in junior schools. Aslib Proceedings, 54 (5), 317-25

Kumar, S (1997). Problems of school libraries in present day education: some observations and solutions. Annals of Library Science and Documentation, 44 (4), $140-2$

Majid, Shaheen and Mokhtar, Intan Azura (2005). Use of school libraries by teachers in Singapore schools. Library Review, 54 (2),108-118.

Matsudo, H (2000). What is an easy-to-use school library layout? [In Japanese] Toshokan Zasshi, 94(7), 492-6.

Olen, S. (1995). Academic success and school library use. School Libraries Worldwide, 1 (1), 69-79.

Prasad, K. N.(2004). Rural school libraries survey: a report. Information Studies, 10 (4), 613-636. 
Ranganathan, S R (1962). Sociology of School Library, The Educational Review, Madras.

Wishart, J (2000). Students' and teachers' perceptions of motivation and learning through the use in schools of multimedia encyclopedias on CD-ROMs. Journal of Educational Multimedia and Hypermedia, 9 (4), 333-47.

Zaman, H. B (1994). The effects of the use of school library resource centres (SLRCs) on students' achievement in English and Malay. International Review of Children's Literature and Librarianship, 9(1), 32-9. 